Images $\ln .$.

\title{
Reversed halo sign in cryptogenic organising pneumonia
}

\author{
Leanne Burke, ${ }^{1}$ Badie K Jacob² \\ ${ }^{1}$ York District Hospital, York, UK \\ ${ }^{2}$ Bradford Royal Infirmary, Bradford, UK
}

Correspondence to Leanne Burke, leanneburke@doctors.org.uk

\section{DESCRIPTION}

A 40-year-old woman was admitted to our respiratory ward with a short history of shortness of breath, non-productive cough and fever. She also complained of pleuritic chest pain on the right and some night sweats. Her exercise tolerance had reduced from $200 \mathrm{~m}$ on the flat to about $20 \mathrm{~m}$. Her medical history included ischaemic heart disease, myocardial infarction, hypothyroidism, fibromyalgia and migraines. She was not immunosuppressed. Six months ago she was also admitted to intensive care with pneumonia. She was an ex-smoker with a 20 pack/year history. There were no risk factors for HIV. On examination she was found to be pale, clammy and breathless. Her oxygen saturations were being maintained at $99 \%$ on 151 non-rebreather mask. On auscultation there was decreased air entry and crepitations at the right mid-zone. Blood tests revealed a normocytic anaemia with raised white cell count at 15000 and $C$ reactive protein greater than 160 . Her chest x-ray showed right middle zone consolidation. It was thought this was community acquired pneumonia and, therefore, she was started on intravenous antibiotics. Due to the pleuritic chest pain a CT scan was ordered to rule out a pulmonary embolus. This showed unremarkable mediastinal lymphadenopathy and right middle lobe consolidation.
Three weeks later she showed no sign of improvement. Other than antibiotics, the only other treatment she had was the recommencement of her usual diuretic to treat heart failure. A further CT scan was ordered and a bronchoscopy was performed. The CT scan showed several new areas of consolidation with a reversed halo sign having appeared in both lungs over this period of time (figure 1). This has been classically described in cryptogenic organising pneumonia (COP); however, it has also been described in tuberculosis, sarcoidosis and vasculitis. Bronchoscopy washings were negative for acid and alkali fast bacilli and there was no growth on culture. Antineutrophil cytoplasmic antibodies were negative. An open lung biopsy was considered in order to obtain a definitive diagnosis, but surgery was judged to be a significant risk in view of the degree of hypoxia. A presumptive diagnosis of COP was made and corticosteroids started (40 mg prednisolone). Her symptoms resolved over a matter of days. A repeat chest x-ray 2 weeks later showed no consolidation or pleural effusion.

Competing interests None.

Patient consent Obtained.
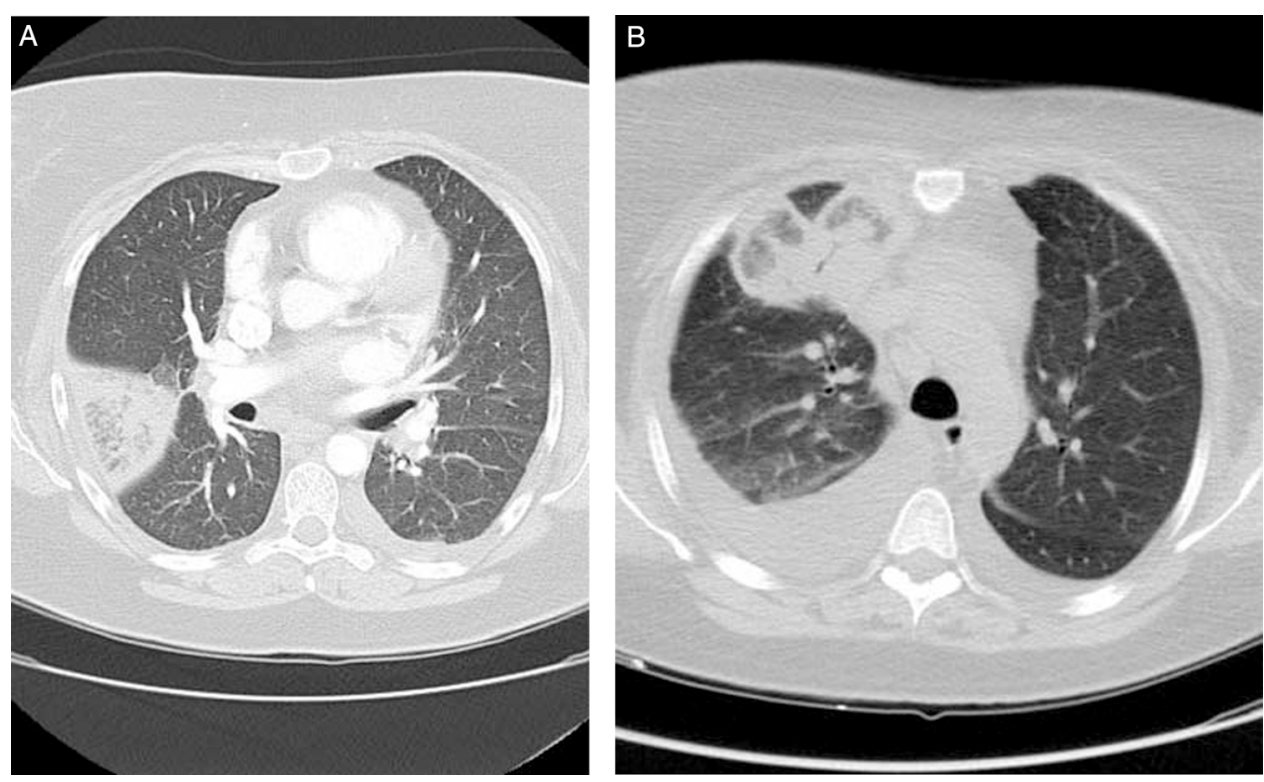

Figure 1 Two examples of reversed halo sign in cryptogenic organising pneumonia. 


\section{BMJ Case Reports}

This pdf has been created automatically from the final edited text and images.

Copyright 2010 BMJ Publishing Group. All rights reserved. For permission to reuse any of this content visit http://group.bmj.com/group/rights-licensing/permissions.

BMJ Case Report Fellows may re-use this article for personal use and teaching without any further permission.

Please cite this article as follows (you will need to access the article online to obtain the date of publication).

Burke L, Jacob BK. Reversed halo sign in cryptogenic organising pneumonia. BMJ Case Reports 2010;10.1136/bcr.03.2010.2824, date of publication

Become a Fellow of BMJ Case Reports today and you can:

- Submit as many cases as you like

Enjoy fast sympathetic peer review and rapid publication of accepted articles

Access all the published articles

Re-use any of the published material for personal use and teaching without further permission

For information on Institutional Fellowships contact consortiasales@bmjgroup.com

Visit casereports.bmj.com for more articles like this and to become a Fellow 